\title{
25 años de fotografiar. Pedro Valtierra, fotógrafo de prensa
}

\author{
Mónica Morales Flores ${ }^{1}$ \\ monica.morales.flores@gmail.com \\ 25 Year of Photography. Pedro Valtierra, \\ Photojournalist
}

\section{Resumen}

El presente texto muestra los primeros 25 años (1975-2000) de la trayectoria de Pedro Valtierra, uno de los fotorreporteros mexicanos más destacados de fines del siglo xx que con su cámara captó acontecimientos relevantes del país y de América Latina en las décadas de los setenta y Palabras clave: México siglo xx, fotoperiodismo mexicano, Pedro Valtierra, Latinoamérica.

\section{Abstract}

This paper depicts the trajectory of Pedro Valtierra's first 25 years (1975-2000) as a photojournalist. Pedro Valtierra is considered one of the most prominent Mexican photojournalist of the late 20th century. During the 1970s and 1980s, he captured Mexican and Latin American important Key words: 20th century Mexico, mexican photojournalism, Pedro Valtierra, Latin America.

1 Centro Universitario de Ciencias Sociales y Humanidades, Universidad de Guadalajara, México.

Guanajuato 1045, Alcalde Barranquita, Artesanos, C. P. 44260, Guadalajara, Jalisco, México. ochenta y el diario acontecer de la ciudad de México. Se trata de un recorrido desde una mirada histórica, enmarcando su trayectoria dentro de un contexto histórico, social, cultural y generacional específicos. events, as well as diverse happenings of the everyday life in Mexico City. So, this article portrays a journey from a historical perspective, framing his career within a specific historical, social, cultural, and generational context. 


\section{Introducción}

Pedro Valtierra es referente obligado cuando se habla del fotoperiodismo mexicano de finales del siglo xx. Sus obras forman parte del imaginario colectivo nacional; baste recordar las icónicas imágenes de los Mineros desnudos (1986), El Subcomandante Marcos (1996), El balazo (1979), Mujeres de X'oyep (1998); los estéticos registros en el desierto de la República Árabe Saharaui Democrática (1982) o las innumerables imágenes de vida cotidiana publicadas en La Jornada en la década de los noventa.

Mucho se habla de su trayectoria fotoperiodística y de su faceta como promotor de la fotografía y ha sido entrevistado en incontables ocasiones por diversos medios de comunicación nacionales e internacionales; sin embargo, repiten la misma información general y pocos abordan de manera profunda y analítica su carrera situándola en el contexto de la fotografía mexicana de fines del siglo xx y en particular del fotoperiodismo. De tal manera que para poder historiar su trayectoria dentro de la historia de la fotografía de prensa se hace necesaria una aproximación que lo sitúe en la trama y urdimbre del "Nuevo Fotoperiodismo mexicano", ${ }^{2}$ más allá de la leyenda mítica del fotógrafo aislado que se hizo solo y ubicándolo dentro de la generación que Luis Jorge Gallegos denomina "creadores de nuevos medios y estilos", formada entre otros por Aarón Sánchez, Christa Cowrie, Pedro Valtierra, Omar Torres y Sergio Dorantes.

2

El historiador John Mraz (1997) ha denominado a este periodo de efervescencia fotográfica "nuevo fotoperiodismo mexicano", cuya principal particularidad es el enfoque crítico y agudo en la vida cotidiana, el registro y la documentación del acontecer diario del pueblo dejando de lado la parte pintoresca, folklórica y amarillista que hasta mediados de la década de los setenta prevalecía en la foto de prensa. Las transformaciones también se dan en el plano estético con experimentaciones en los encuadres, composiciones y estrategias visuales, aunadas a imágenes chuscas, agudas y perspicaces donde el sarcasmo, la ironía, el humor y la burla se ven reflejados en los rostros de los políticos retratados en actitudes inusuales para su investidura, con muecas ridículas, es decir, los desacralizan. En las imágenes de vida cotidiana se ven manifestadas las contradicciones entre el discurso oficial y la realidad nacional. "El punto esencial es un cuestionamiento de las estructuras de poder que han sido dominantes" buscando "el lado irónico para romper la imagen del poder". Esta nueva forma de hacer periodismo gráfico encuentra su escaparate en el diario Unomásuno, impulsado por Manuel Becerra Acosta, y traza así el camino del periodismo gráfico de las siguientes décadas e inaugura el boom de la fotografía de prensa mexicana que se extiende a La Jornada en los años ochenta. 
A esta generación le toca asumir responsabilidades y vivir un cambio sustancial en los medios de comunicación y el uso de la fotografía en esos espacios [...] en ellos se vislumbran cambios importantes y nuevos enfoques en su trabajo cotidiano. Su aportación se da en distintos niveles y ángulos de la fotografía de prensa mexicana, que dentro de las nuevas condiciones de los medios permitía hacer exploraciones y propuestas distintas de lo acostumbrado (Gallegos, 2011, p. 44).

En este sentido, el texto busca recuperar la trayectoria de Valtierra a partir del testimonio del propio fotógrafo y de algunos colegas, en diálogo con fuentes bilbiográficas, hemerográficas y de archivo. ${ }^{3}$ Lo situamos en un escenario definido para poder entender su forma de fotografiar, su formación periodística, su postura ideológico-política así como el contexto en el que se inicia y desarrolla como fotorreportero, sin olvidar que corresponde a circunstancias históricas que lo definen como fotógrafo. Vivió en la década de efervescencia fotográfica y el desarrollo de un periodismo que impulsó a los reporteros y periodistas a recurrir a elementos literarios que lograron que sus textos fueran leídos como una novela para provocar al lector, sazonado con la interpretación personal y con recursos pertenecientes al "realismo social", con el objetivo de describir los cambios que el mundo está experimentando en todos los niveles, es decir, un periodismo social. Esas características se trasladan a la fotografía de prensa, tal como lo plantea Tom Wolf (1976, p. 9).

Este artículo parte del análisis de fuentes hemerográficas y orales, dejando en esta ocasión las imágenes como ejemplo del trabajo de Valtierra. ${ }^{4}$ Los testimonios orales se abordan con las premisas de Graciela de

Los documentos manuscritos inéditos y algunos artículos periodísticos utilizados para este texto se encuentran en el FDPV. Hasta agosto de 2011, gran cantidad de documentos que contienen la trayectoria de este fotógrafo se encontraba guardada sin ningún orden archivístico; no fue hasta el inicio de la investigación para la exposición Pedro Valtierra. Mirada y testimonio que inició una ardua y minuciosa revisión del material. De agosto de 2011 a enero de 2012 me di a la tarea de organizarlo a partir de los espacios donde trabajó, comenzando con la Presidencia (1975) y concluyendo con la Fototeca de Zacatecas (2006).

Es tan vasta la producción de Valtierra que cada uno de los temas fotografiados merece un estudio independiente para poder profundizar en ellos. Como se explicó, se busca recuperar su trayectoria y situarlo en el contexto general de la fotografía mexicana al finalizar el siglo xx. Existen otros textos tratados desde la academia, como los de Sandra Pérez en cuya tesis de licenciatura en Estudios Latinoamericanos analiza el libro Nicaragua. Una noche afuera a partir de la desintegración de la narrativa visual 
Garay y Jorge Aceves, que plantean que el interés de la historia oral es conocer y comprender la dinámica de los grupos sociales y la preocupación por los hechos y fenómenos de determinados procesos económicos, políticos y culturales a partir de

testimonios orales recogidos sistemáticamente para investigaciones específicas, bajo métodos, problemas y puntos de partida teóricos explícitos [...] para producir conocimientos históricos científicos y no simplemente lograr una exposición ordenada de fragmentos y experiencias de vida de "otros",

es decir, generar nuevas fuentes, estudiarlas y valerse de ellas como herramienta histórica (Aceves, 2000, p. 10).

El análisis de la trayectoria del fotógrafo se realiza a partir de los planteamientos de referentes obligados en la historia del fotoperiodismo en México: Alberto del Castillo, Rebeca Monroy y John Mraz, que sugieren su estudio desde la historia social, cultural y oral, a partir de los usos sociales de las imágenes y las múltiples lecturas de quienes las producen, reciben e interpretan dentro de su contexto histórico, lugar de producción y medios de difusión. Ligadas a los autores clásicos Boris Kossoy (2001) con su teoría de las tres realidades de la imagen y los niveles de descripción e interpretación; Joan Fontcuberta (1994), que afirma que

las fotografías son "leídas" según diversos criterios y toda lectura dependerá de dónde apuntamos; en la intención del fotógrafo, en el acto mismo de la fotografía, en la fotografía por ella misma, en la relación

\footnotetext{
inicial del catálogo y la clasificación de las imágenes para mostrar el diálogo entre ellas, sin olvidar cotejarlas con lo publicado en Unomásuno e integrarlas nuevamente a la lógica editorial del libro. Otro acercamiento es la tesis de maestría en Historia de Susana Rodríguez titulada La mirada crítica del fotorreportero Pedro Valtierra (1977-1986), que permite conocer pormenorizadamente los primeros diez años de Valtierra como fotógrafo de prensa, a partir del análisis de las imágenes publicadas en El Sol de México, Unomásuno y La Jornada. Los datos duros, la rigurosa metodología empleada, las variables de estudio propuestas para el análisis cuantitativo de las aproximadamente 3500 fotografías publicadas colocan a esta tesis como uno de los acercamientos mejor logrados a la obra de Pedro Valtierra. Por mi parte, concluí una investigación (20082011) centrada en la cobertura fotoperiodística de la revolución sandinista, de la que se han derivado varios artículos publicados en diversos medios y formatos. Mención aparte merece la exposición Pedro Valtierra. Mirada y testimonio (CCUT-UNAM, 2012), que recorre las primeras tres décadas de su trabajo.
} 
entre ella y el contexto a través del cual se difunde y en el efecto causado en un determinado espectador (p. 131),

y Peter Burke (2001), con su acercamiento a la imagen como documento histórico a partir del análisis iconográfico e iconológico, es decir, el estudio tanto de elementos dentro de la imagen como factores externos involucrados en ella que permiten una lectura amplia y completa. Pues si bien las imágenes de Valtierra no se analizarán, es necesario abordar al autor desde los estudios visuales y en particular del fotoperiodismo nacional.

\section{El hallazgo. Presidencia de la República (1975-1977)}

Pedro Antonio Valtierra Rubalcaba nace en 1955 en la población San Luis de Ábrego, municipio de Fresnillo, Zacatecas. En 1969 se traslada con su familia a la ciudad de México y vive en Tacubaya. Ingresa a sexto de primaria en el turno vespertino y por la mañana se desempeña como bolero en los alrededores del bosque de Chapultepec. En esos años llega por casualidad a la casa presidencial de Los Pinos, donde es contratado por Mauro Nuño Jiménez como bolero del Estado Mayor. A partir de ese momento Valtierra asciende escaños hasta que en 1973 ingresa como ayudante del laboratorio de fotografía del departamento de Comunicación Social de la Presidencia. Su primera aventura periodística independiente la lleva a cabo mientras cursa la educación media básica; se trata de una gacetilla estudiantil titulada La Voz Estudiantil (1974-1975). Este folleto mensual representa una tribuna donde se exponen problemas sindicales de sus compañeros, inquietudes sociales y conflictos internos de la secundaria. $^{5}$

Como asistente del laboratorio, llegó la oportunidad esperada para debutar como fotógrafo. Valtierra así lo recuerda:

Un día se fueron a comer todos los fotógrafos titulares y llegó Mauro Nuño Jiménez -Capitán del Estado Mayor Presidencial- preguntando por un fotógrafo; le respondí que no había nadie, pero ellos sabían que yo tomaba fotos y revelaba porque tenía dos años haciéndolo; tenía

Siendo alumno del CCH Naucalpan organiza otro boletín mensual, Unidad, que al igual que La Voz estudiantil busca ser un órgano de difusión de la vida universitaria. En esta etapa combina el pasatiempo de dibujar con su afición al futbol y el box, que practica como amateur. Este gusto lo lleva a escribir su primera nota periodística al iniciar la década de los setenta en la revista El Boxeo Ilustrado, dirigida por Hernando Mendoza, al entrevistar al boxeador minimosca Valentín el Duende Martínez. 
una cámara miranda y un lente $50 \mathrm{~mm}$. Me manda a la residencia oficial a un evento que tenía el presidente y lo cubrí; revelé e imprimí las fotos, las vio Mauro y me dijo: "tomas buenas fotos", y bueno, esto se repitió unas dos o tres veces más (Valtierra, 2011).

A partir de esta experiencia, Agustín Pérez toma la decisión de dejar una cámara en caso de que esto suceda nuevamente. Esa ocasión llega el domingo 19 de abril de 1975. Luis Echeverría regresa de una larga gira y ese mismo día tiene un acto público a las 8 de la mañana en la unidad deportiva de la Magdalena Mixhuca. Sin fotógrafos disponibles, Mauro Nuño comisiona a Valtierra para cubrir el suceso. Al día siguiente sus imágenes se publican en la portada de El Nacional, El Heraldo y El Día. Valtierra le muestra los diarios al director de Información de la Presidencia, y a partir de ese momento lo ascienden a fotógrafo.

Cuando entré al laboratorio de la presidencia vi las tarjas, las fotos, las charolas y me quedé parado; cuando me acerqué, eso me encantó. Me gustó solamente, me encantó el olor, me pareció que era una cosa mágica, la foto aparecía como magia. Cuando conozco el laboratorio, para mí la vida cambia. Ese momento fue muy importante; no lo quiero magnificar, pero me embrujó la fotografía (Valtierra, 2011).

Como trabajador de la Presidencia, Valtierra se relaciona con los fotógrafos Agustín el Chino Pérez, que trabajó en Novedades y La Prensa; Manuel Madrigal, salido de la revista Siempre!, y el laboratorista Leopoldo Morales. Ellos son sus maestros, y la Presidencia se convierte en una escuela. También aprende de Raúl Anaya, Salvador González y Carlos Macías. Sin embargo, Madrigal es clave en la formación de Valtierra, pues además de introducirlo en los secretos químicos del laboratorio, le enseña a mirar, encuadrar, fotografiar y pensar la imagen para disparar poco, pero pensado. Calidad antes que cantidad.

Madrigal tomaba con su Hasselblad doce placas en un evento de Echeverría. Yo veía como trabajaba; ninguna era igual, ninguna fuera de foco, ninguna con flash. Yo preparaba los químicos y él revelaba. Madrigal me decía: "no puedes tomar fotos a lo tonto, tienes que ver, tienes que esperar". Me acuerdo que me dio un rollo y me dijo: "lo tomas así, cambias velocidad, revisas diafragma y revelas, tú solo te vas a dar cuenta y vas a anotarlo en un cuaderno". De las 36 tomas me iban a quedar bien dos, pero no me decían cuáles, yo tenía que verlo; entonces me preguntaban: "¿cuál es la mejor?" "Ésta”, les decía. “¿Qué 
exposición y velocidad le diste?" "Pues tal". Crecí con una formación de austeridad y de ver antes de disparar (Valtierra, 2011).

Sin duda la lección más importante que Pedro Valtierra recibe de Manuel Madrigal es escribir con luz. Valtierra recuerda esa lección como una de las más importantes en su carrera. "El día que le pierda el miedo a la luz, ese día Pedrito va a ser fotógrafo. Dominar la luz es dominar el drama, dominar el dolor. Quien no respeta la luz como fotógrafo, se jode; la fotografía es luz, y mientras no comprendas la luz no hay nada".

Como todos los fotógrafos, Valtierra tiene referentes visuales, maestros de quienes aprende estilos, formas de mirar, con quienes comparte intereses, discute y se nutre. Su primer acercamiento a fotorreporteros consagrados se da de manera estrecha con los hermanos Mayo, en particular con Julio Mayo, entablando una relación estrecha. Con Héctor García y Nacho López también convive y aprende, pero de manera esporádica, y más tarde conoce a Rodrigo Moya. ${ }^{6}$ Éstos son sus referentes nacionales. $\mathrm{Su}$ contacto con fotógrafos extranjeros, en particular con corresponsales de guerra, lo tiene en Nicaragua (1979) y a través de exposiciones, libros y noticias llegadas al país de trabajos como los de Cartier-Bresson y Robert Capa.

Su trabajo en la Presidencia no representa mayores retos. En un momento en que la figura del primer mandatario es cuidada en exceso y los cánones estéticos permitidos no van más allá del retrato en close-up, Valtierra no tiene mucho campo para desarrollarse. Es con la llegada de la nueva administración que decide renunciar a la Presidencia e ingresa a El Sol de México.

\section{La práctica. El Sol de México (1977-1978)}

Pedro Valtierra ingresa al periodismo gráfico el domingo 13 de marzo de 1977 como fotógrafo de base en El Sol de México, donde pone en práctica

Los fotógrafos citados representan la generación de medio siglo, "Herederos fotográficos del siglo xx", como los llama Luis Jorge Gallegos (2011). Entre los más destacados podemos citar a Walter Reuter, los hermanos Mayo, Francisco Patiño, Enrique Bordesmangel, Héctor García, Enrique Metinides y Rodrigo Moya. Este reducido grupo se enfrentó al anquilosamiento de la fotografía de prensa, caracterizada por imágenes estáticas donde la norma era retratos en close up de la elite política y donde el pueblo mexicano no tenía cabida. Esta generación constituye uno de los eslabones más importantes del fotoperiodismo mexicano. 
los conocimientos adquiridos en la Presidencia. ${ }^{7}$ En la página 2A de la edición matutina de ese día se publica su primera fotografía de vida cotidiana, unos jóvenes "echándose una cascarita" en la Unidad Tlatelolco de la ciudad de México. A partir de ese momento aparecen regularmente imágenes de vida cotidiana, policía y, esporádicamente, de la política nacional con el crédito "Fotografía de Pedro Valtierra". Como cualquier reportero nuevo, comienza cubriendo la fuente policiaca. Por la mañana trabaja en el diario y por la tarde asiste al Colegio de Ciencias y Humanidades de la UNAM. ${ }^{8}$

Me asignan un equipo fotográfico y me mandan a la policía, llegaba a la Cruz Roja y esperaba que hubiera accidentes, muertos, choques. Mientras, iba al CCH. Así estuve dos o trs meses, y luego me empezaron a dar otras cosas; me quitan de policía y empiezo a hacer muchos espectáculos. Llegaba al periódico con mi rollo de transparencias, revelaba, cortaba la foto, le pegaba con un diúrex en la orillita y le ponía: fulano de tal, se entrevista con tal, o reportaje de "el calor en Chapultepec", los datos que ubicaban la foto, tu nombre y la fecha. La preselección la ponían conforme iba llegando en una mesa de luz grande que estaba en el centro, ahí Wong decidía cuáles iban a portada y cuáles a interiores. Wong, con cuentahilo, seleccionaba las imágenes, trabajaba junto a nosotros, junto al editor y al jefe de redacción (Valtierra, 2011).

Esporádicamente $E l$ Sol publica reportajes escritos y fotografiados por Valtierra realizados en el interior de la República sobre temas específicos, como minería, pesca, comunidades marginadas, petróleo o fauna mari-

El Sol de México representa el primer laboratorio de la fotografía de prensa; su director, Benjamín Wong, experimentó con fotoensayos y vida cotidiana cuando ambos conceptos eran poco explotados. El género de "vida cotidiana" no existía propiamente como tal. Esporádicamente se publicaban fotografías con escenas del pueblo, pero eran escasas. Para el caso de los fotoensayos, su espacio tradicional eran las publicaciones periódicas y no la prensa diaria, que por la inmediatez de la noticia hacía difícil realizar un trabajo de mediano o largo alcance que implicaba investigación y selección de imágenes para construir un hilo narrativo a manera de historia visual.

8 De acuerdo con el análisis cuantitativo de Susana Rodríguez, durante los meses que trabaja en el diario le publican 197 fotografías, de las cuales 143 son a color y 54 en b/n. El 94\% de ellas tienen crédito fotográfico. Los reportajes especiales de una o dos entregas se publican en la edición matutina, ya que se trata de trabajos realizados días antes, lo que permite construir un discurso narrativo más pensado (Rodríguez, 2012). 
na. En este periodo inicia dos proyectos personales de largo alcance: la comunidad menonita y la recuperación de su patria chica.

El 6 de octubre de 1978, el crimen de los Flores Muñoz conmociona a la clase política nacional y la prensa sigue pormenorizadamente el caso. En la edición de mediodía del 12 de octubre, El Sol de México publica diez fotografías de Pedro Valtierra y Carlos Macías, cuatro en primera plana. Una de ellas está ubicada en la parte media superior de la página.

El estilo fresco de Valtierra queda plasmado en esta imagen. Mientras que sus colegas se centran en fotografiar el rostro del asesino confeso arremolinándose frente a él, Valtierra observa a distancia y decide enfocar las armas homicidas, dejando en segundo plano al grupo de reporteros gráficos, con un marcado punto de fuga, característica de las composiciones de esta nueva generación de fotógrafos de prensa. Esta imagen le abre las puertas a un nuevo diario con apenas un año de vida.

Publiqué una foto en 1978 de un caso muy sonado. Gilberto Flores Muñoz fue asesinado por su nieto y me toca darle seguimiento como fotógrafo de la policía. Una foto se publica en portada, son dos machetes que salen de una mesa, y al fondo la conferencia de prensa del procurador Alanís, y esa foto me vale para irme a Unomásuno. Cuando ven la foto en el periódico, Christa Cowrie me invita a trabajar en él (Valtierra, 2011).

La invitación llega en buen momento. El fotógrafo, que ya muestra inquietudes políticas, tiene problemas con el sindicato del diario. Con la crisis a cuestas, el ofrecimiento de Christa Cowrie es la mejor salida para su futuro profesional.

\section{La profesionalización. Unomásuno (1978-1984)}

El Sol de México le permite afianzar sus conocimientos técnicos, pero es en el Unomásuno donde agudiza su mirada e inicia un incipiente estilo fotográfico que desarrolla paulatinamente y que alcanza su madurez en La Jornada. $^{9}$

El Unomásuno, fundado en noviembre de 1977 por el periodista Manuel Becerra Acosta, representó además del vehículo para legitimar la reforma política de López Portillo, un escaparate para el periodismo moderno que surgía en el país. Las primeras placas de Valtierra en este diario se publican el 26 de octubre de 1978; éstas registran un accidente automovilístico en la colonia Nueva Atzacoalco de la ciudad de México. "19

heridos al chocar un transporte escolar", Unomásuno, 26 de octubre de 1978. Al no 


\section{Imagen 1}

El Sol de México

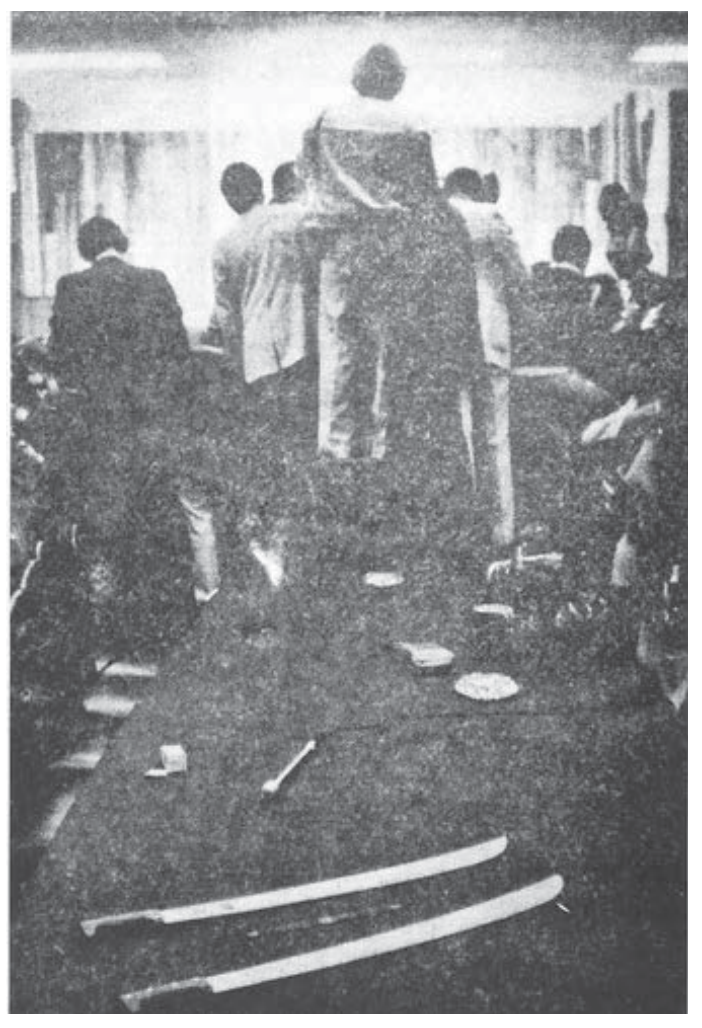

12 de octubre de 1978, Pedro Valtierra, Biblioteca Miguel Lerdo de Tejada, SHCP.

Pedro Valtierra se inicia como fotógrafo de prensa en un contexto favorecedor para la fotografía de prensa mexicana. Como explicamos líneas arriba el "nuevo fotoperiodismo mexicano" representaba un impulso fresco y prometedor para la fotografía. Su trabajo cotidiano en El Uno no es diferente al de El Sol. Asistir al CCH por la tarde y cumplir las órdenes diarias por la mañana, regresar para revelar, seleccionar, imprimir, hacer los budgets e intercambiar con sus colegas las inquietudes por la fotografía, en particular con la fotorreportera Martha Zarak. Valtierra sólo encuentra tres diferencias entre ambos diarios.

El equipo te lo daba el Unomásuno; nos daban cargas porque no tenían muchos recursos, compraban películas de cien pies y hacíamos cargas tener sección de policía, los hechos violentos o accidentes de la capital se tratan como asuntos de la ciudad y se publican en esta sección. Esa fuente la cubre Valtierra hasta que es enviado a Nicaragua. 
de 36, cuando ibas de viaje te daban un cargador, tres latas de película, y tu tenías que hacer tus rollos. Otra diferencia eran las juntas; era más vertical, porque el director y los jefes de información decidían que iba y que no iba, tú no entrabas a ellas, sólo el jefe de fotografía. El director se sentaba a la cabeza de la mesa, estaba Carlos Payán, el jefe de información, el de redacción y el de cada fuente con el budget de los adelantos y Becerra Acosta preguntaba "-ique traes?", "-política, diez notas, para ver qué es lo que sugiere; deportes, cinco notas; cultura, tantas". Tu preselección de fotos la ponías frente al director, un paquete de cuatro o cinco, y elegían las que se publicarían; así aprendí que no debías meter tantas fotos: tenías que decidir, porque si dabas muchas opciones podían publicar la que no era. Así aprendes a editar y a seleccionar (Valtierra, 2011).

En ese periodo, Valtierra se estrena como enviado para realizar con Víctor Avilés reportajes especiales dentro del país. En abril de 1979 viaja a Nicaragua como corresponsal de guerra, y a partir de ahí a otros países centroamericanos. ${ }^{10}$ Manuel Becerra Acosta decide enviarlo a cubrir la revolución sandinista, y permaneció en ese país hasta agosto del mismo año. La importancia que el diario da a su trabajo le da una proyección poco vista en la prensa de la época. ${ }^{11}$ Este viaje significa el antes y después en su carrera, la difusión de sus imágenes en Unomásuno le abre las puertas del fotoperiodismo nacional e internacional y, sin proponérselo, de la fotografía de autor. ${ }^{12}$

10 Los reportajes nacionales e internacionales más destacados que realiza de 1979 a 1984 son: El Trapiche, Oaxaca (1979); Menonitas, Zacatecas (1979); Xococapa, Veracruz (1980); Golonchán, Chiapas (1980); Triquis (1981); Nicaragua (1979); Refugiados guatemaltecos (1981-1982); El Salvador (1980-1982); RASD (1982). Para acercarse a profundidad a los fotorreportajes publicados, las imágenes iconos, los proyectos personales y su veta como empresario y promotor de la imagen, puede verse Castillo y Morales, 2012. les, 2014.

La Universidad Autónoma Metropolitana, plantel Xochimilco, lo invita en octubre de 1979 para exponer su trabajo de Nicaragua. De 1979 a 1984 Pedro Valtierra se hace acreedor a once premios y reconocimientos, entre ellos una mención honorífica del premio Casa de las Américas en 1982 por su trabajo "Revolución sandinista"; en 1983 repite la mención con la serie "Bienvenidos a la tierra del quetzal", con imágenes de los desplazados guatemaltecos. Ese mismo año gana el Premio Nacional de Periodismo por su trabajo en Centroamérica (Nicaragua, Guatemala y El Salvador), que repite en 2013 por su trayectoria fotográfica de 38 años. Paradójicamente, en 1983 Unomásuno lo 
La cobertura de la revolución sandinista dio como resultado más de 400 imágenes, entre las que destacan El balazo. Esta fotografía que sintetiza la lucha del pueblo nicaragüense ha recorrido los tres estadios de los que habla Kossoy, desde su publicación en junio de 1979 a su exhibición en museos y galerías sin olvidar los usos que ha tenido en carteles, invitaciones, postales, ilustración de artículos u objeto de análisis para los estudios visuales. ${ }^{13}$

En 1981 es invitado por Nacho López al Grupo de los cinco, agrupación independiente que busca otras alternativas de expresión, integrado por Nacho López, Alicia Ahumada, Víctor León, David Maawad y Pedro Valtierra. Más tarde se unen Javier Landeros, Luis Humberto González y Rubén Cárdenas Pax, cambiando su nombre a Grupo de los ocho.

\section{Imagen 2}

"El Balazo"

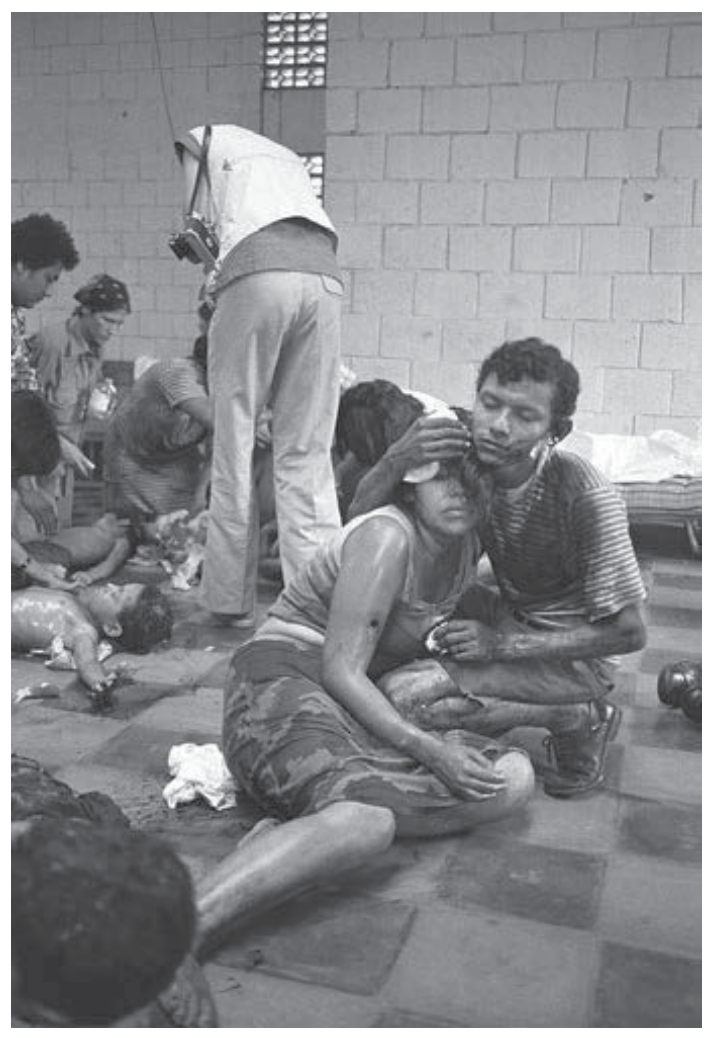

Managua, Nicaragua, 1979, Pedro Valtierra, Archivo Fotográfico Pedro Valtierra (AFPV).

regresa a cubrir Ciudad, fuente en la que permanece hasta marzo de 1984, cuando renuncia al diario.

13 Un acercamiento a esta imagen puede consultarse en Morales, 2016. 


\section{Imagen 3}

El pueblo nicaragüense y guerrilleros sandinistas festejan el triunfo en la Plaza de la revolución

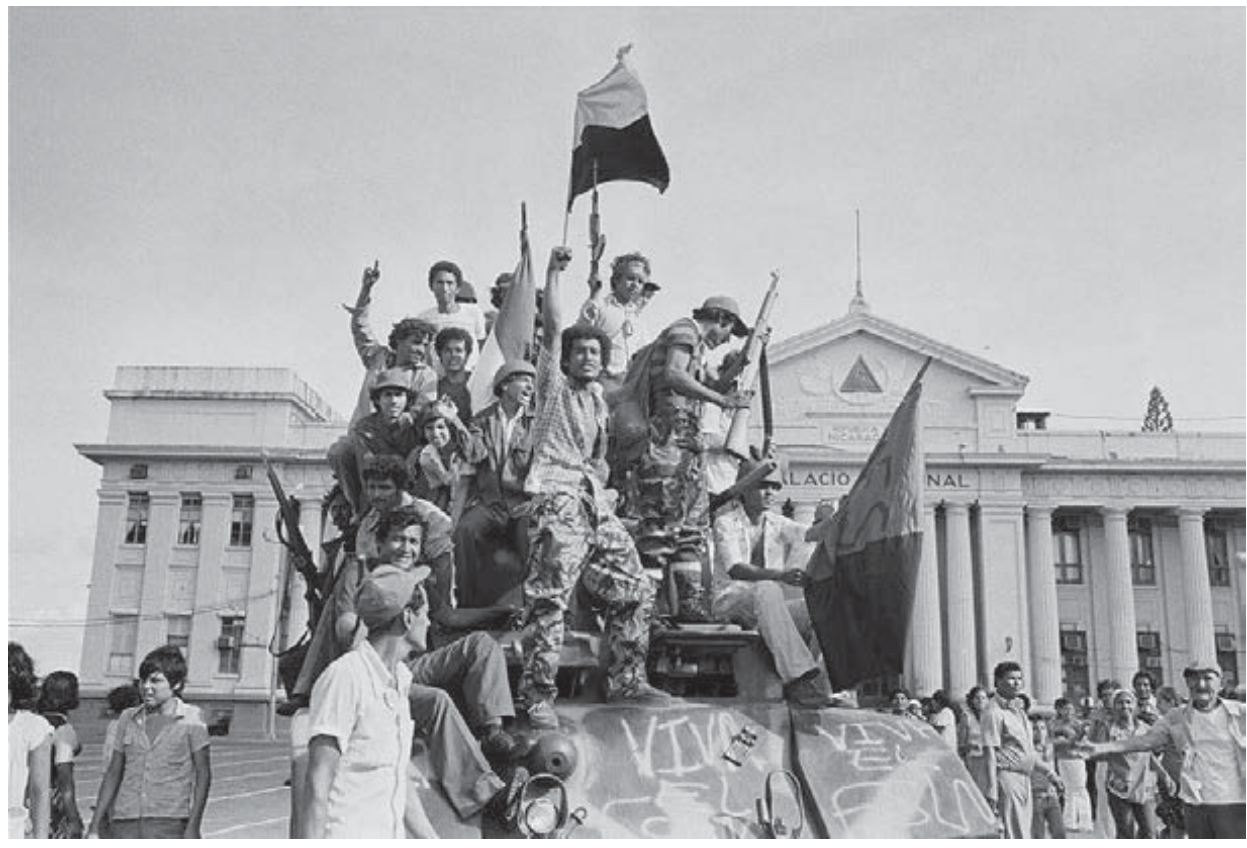

Managua, Nicaragua, 1979, Pedro Valtierra, AFPV.

También integra al lado de 32 fotógrafos la Colectiva de Fotógrafos Unidos, asociación cuya plataforma ideológica es "unir a las diferentes corrientes de fotografía para que converjan en un proyecto en común, rescatando su potencial plástico, experimental y científico". ${ }^{14}$

Valtierra viaja a Guatemala y a la frontera con Chiapas en cuatro ocasiones, con el reportero Miguel Ángel Velázquez, para registrar el éxodo de guatemaltecos a tierras mexicanas a causa de la guerra (1981) y los desplazamientos internos en el Petén (1982). Ese mismo año se interna un par de veces a la selva guatemalteca con los grupos guerrilleros de la Organización del Pueblo en Armas (ORPA) y las Fuerzas Armadas Rebeldes (FAR), con Velázquez y Víctor Avilés, respectivamente. ${ }^{15}$ En 1980 viaja a El Salvador para dar cuenta de los refugiados en Honduras, que huyen de

14 FDPV, Estatutos, Documento mecanografiado, 1981.

15

En el FDPV se encuentra un diario del segundo viaje escrito por Valtierra; en él describe su estancia en el campamento guerrillero. En diciembre de 1996, con la firma de los acuerdos de paz entre el gobierno guatemalteco y los grupos guerrilleros, Valtierra regresa a fotografiar el momento. Este trabajo se publica en La Jornada. 
los enfrentamientos entre la Guardia Nacional y las Fuerzas Armadas de la Resistencia Nacional (FARN) de la represión desatada en los funerales de Monseñor Arnulfo Romero, y como miembro de la comitiva que recoge el cuerpo de su colega Ignacio Rodríguez Terrazas, asesinado por el ejército salvadoreño. El éxodo del puerto de El Mariel en Cuba también es retratado por Valtierra en 1980. El último trabajo como enviado al exterior que realiza en Unomásuno es a África en 1982. El Frente Polisario lo invita para mostrar al mundo a través de sus fotografías la lucha que enfrenta para lograr la libertad de la República Árabe Saharaui Democrática. ${ }^{16}$

La proyección y circulación de las fotografías de este último reportaje se ha dado en espacios museísticos por su lenguaje visual identificado con el arte y no con las características de la imagen noticiosa o el documento histórico, a pesar de que éstos fueron su objetivo primigenio.

\section{Imagen 4}

Campo de refugiados

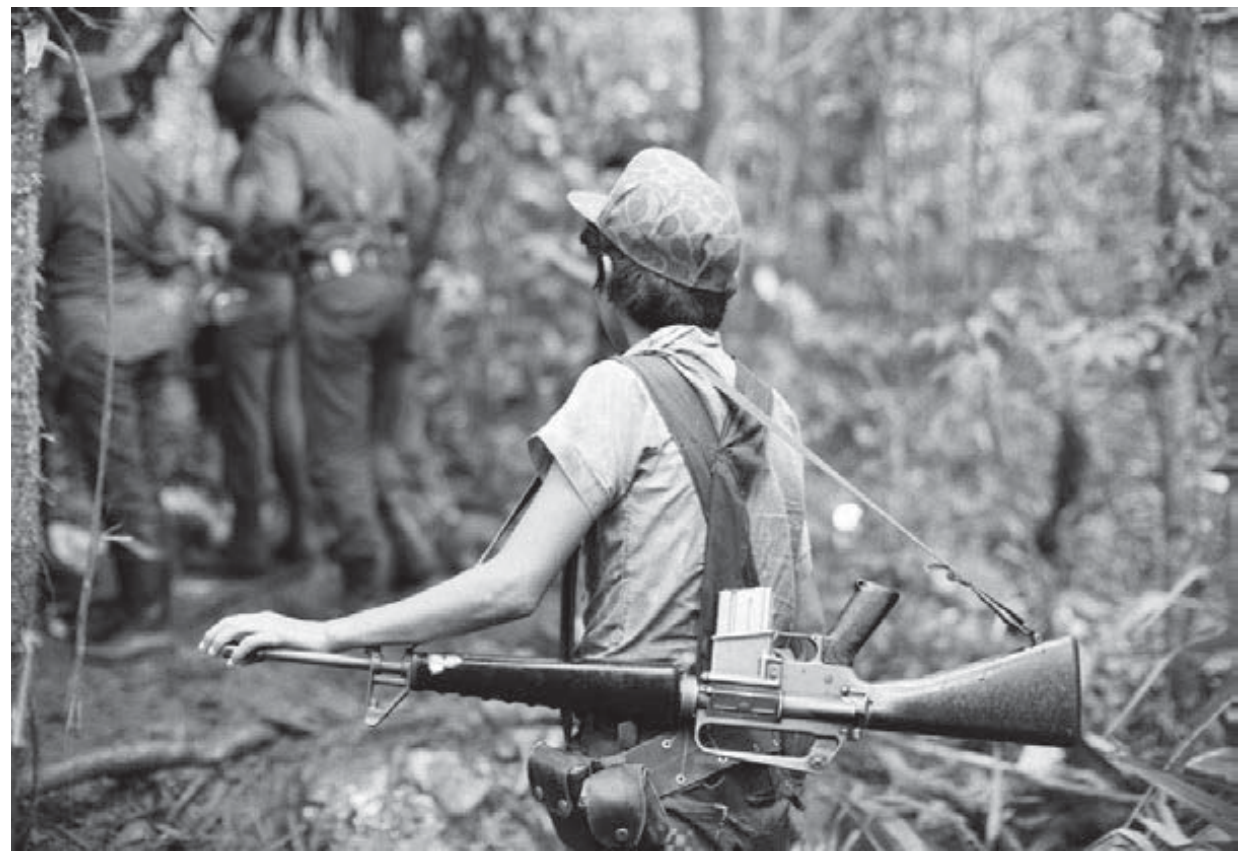

República Árabe Saharahui Democrática, 1982, Pedro Valtierra, AFPV.

16 Este fotorreportaje, cuyo texto e imágenes son autoría de Valtierra, es financiado por el Unomásuno y la revista Por esto! En el diario se publican dos notas (10 y 11 de mayo de 1982) y en la revista cuatro largos reportajes (27 de mayo y 3, 10 y 17 de junio de 1979). 


\section{Imagen 5}

Organización Revolucionario del Pueblo en Armas (ORPA)

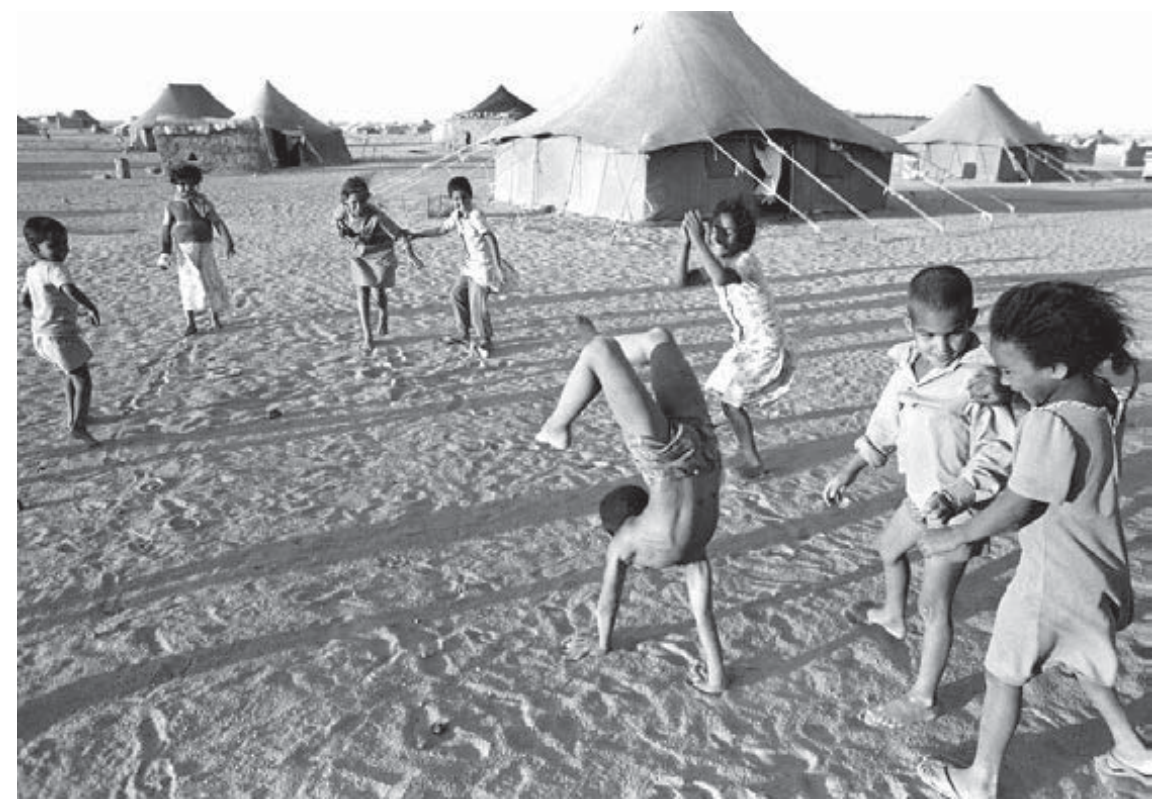

Guatemala, 1982, Pedro Valtierra, AFPV.

\section{Imagen 6}

Visita de Juan Pablo II a México

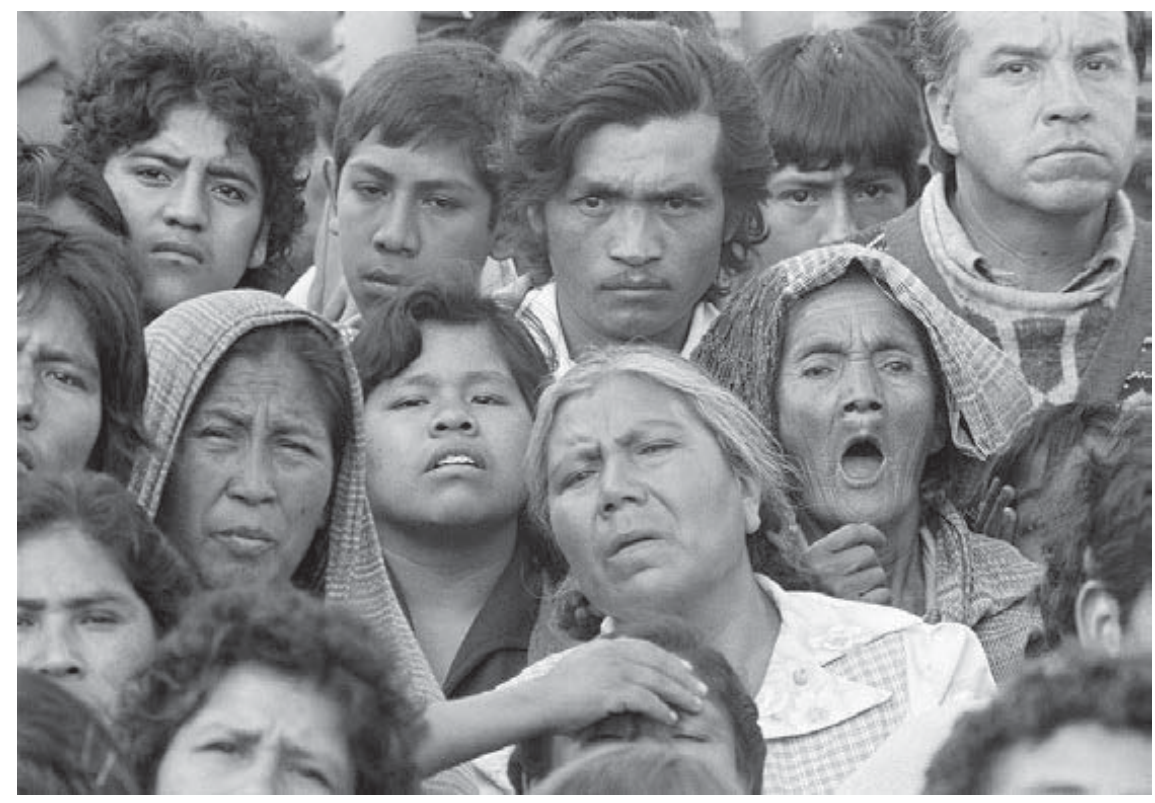

Puebla, México, 1979, Pedro Valtierra, AFPV. 


\section{Imagen 7}

Toma de posesión de Miguel de Madrid

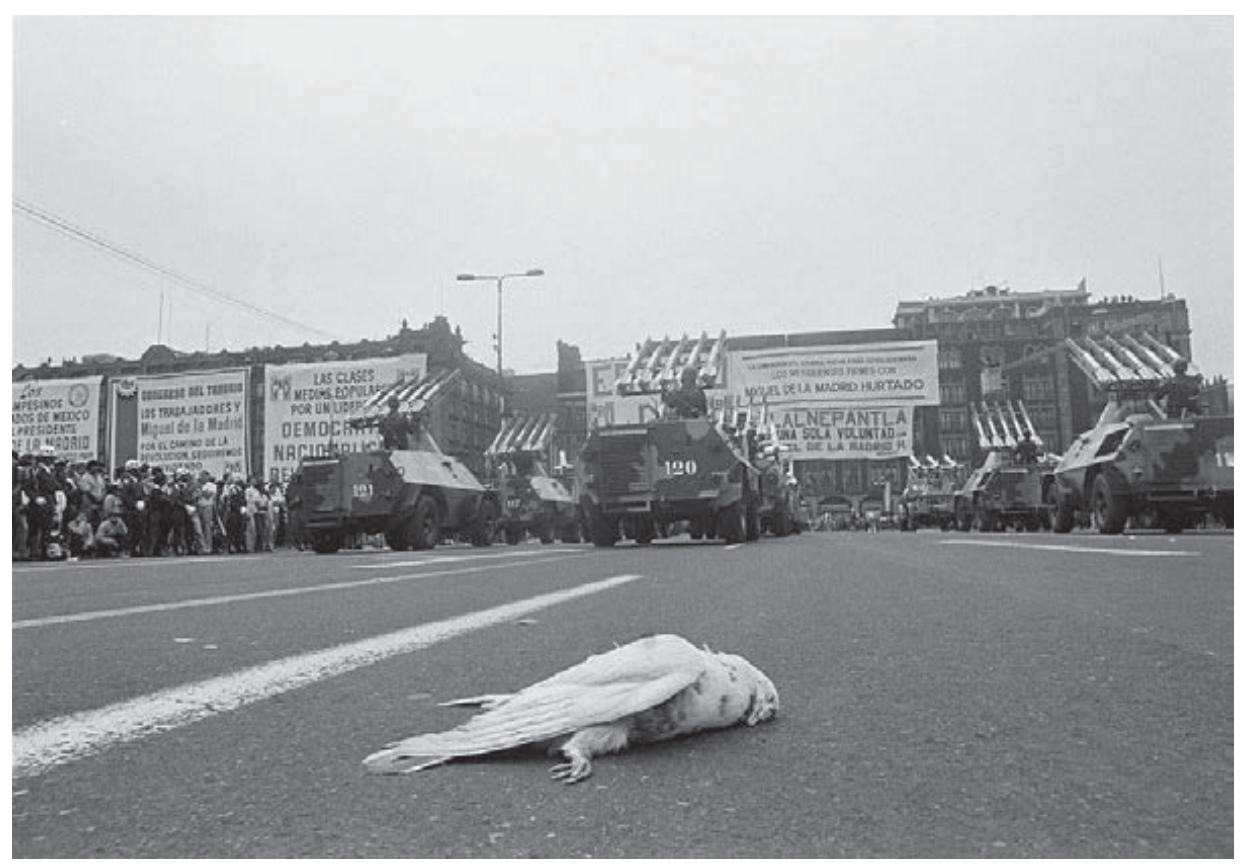

México, 1982, Pedro Valtierra, Banco de Imágenes, Cuartoscuro.

Muchos factores intervienen para que Pedro Valtierra renuncie al diario. Su regreso a cubrir asuntos menores tras recibir el Premio Nacional de Periodismo, como una especie de sanción nunca aclarada; su activa militancia en el SITEUNO que le acarrea pugnas con Luis Gutiérrez, secretario general del sindicato; la tensa calma luego del enfrentamiento por la incapacidad de la administración y dirección del diario de resolver la solicitud de un aumento salarial de emergencia y, finalmente, la compra de Manuel Becerra Acosta del $40 \%$ de las acciones que el socio comercial pone a la venta, convirtiendo al director en dueño del diario. Dicha decisión, tomada sin consultar a accionistas y cooperativistas, produce inconformidades y enfrentamientos irreconciliables que llegan a su punto más álgido a principios de diciembre de 1983, tal como lo documenta el libro Por la izquierda. Medio siglo de historias en el periodismo mexicano contadas por Granados Chapa (Cherem, 2010). ${ }^{17}$ En este contexto de enfrentamientos políticos, periodísticos y berto Musacchio (jefe de redacción), Carmen Lira (subdirectora de información), Héctor Aguilar Camín (asesor del director) son destituidos de sus cargos por manifestar su rechazo a la forma en que Becerra Acosta se hace dueño del diario y las contradicciones 
administrativos, Valtierra toma la decisión de renunciar en marzo de 1984. Había muchas opiniones respecto a la salida, como lo recuerda el fotógrafo:

Tenía muchas dudas, habían pasado muchas cosas, y cuando Becerra Acosta me pidió que no me fuera, sentí que tenía razón. Entonces convoqué a Adriana Malvido, Javier Molina, Miguel Ángel Velázquez, Víctor Avilés, nos reunimos para decidir que debíamos hacer, en ese momento Víctor y Miguel Ángel estaban convencidos de salirse. Al final decidimos que nos íbamos todos (Valtierra, 2011).

Durante la presentación del nuevo proyecto impulsado por los periodistas salidos del diario, Carlos Payán invita a Valtierra a integrarse como coordinador de fotografía de un nuevo rotativo. Tras su salida negocia sus acciones por sus negativos, rescatando el material más importante.

Cuando me voy del Uno, empieza la negociación de las acciones. Me informan que quieren comprar mis acciones, yo accedo a cambio de que me entreguen todos mis negativos. Accedieron y pude recuperar entre otras cosas lo de Nicaragua. Así terminó mi relación con Unomásuno (Valtierra, 2011).

Al salir del periódico funda la Agencia de Fotografía Imagenlatina, al lado de Marco Antonio Cruz, Luis Humberto González, Jesús Carlos y más tarde Fabrizio León. La agencia fotográfica de información y documentación periodística independiente, organizada en cooperativa, tiene como objetivo registrar los acontecimientos sociales, políticos y culturales y comunicarlos a través de una visión continental.

Imagenlatina es una asociación independiente integrada por cinco fotógrafos cuya formación se ha desenvuelto dentro del campo fotoperiodístico en México y América Latina. Es su interés el mostrar por medio de la imagen las estructuras del poder, los mecanismos represivos, la explotación laboral y cotidiana y las formas de organización progresista de los pueblos, para así por medio de la difusión editorial e itinerante tratar de crear una visión crítica y realista de la sociedad en que vivimos (Valtierra, 2011). ${ }^{18}$

entre el proyecto original de cooperativa y el status actual de empresa, con Becerra Acosta como único dueño.

18 Existen tres documentos que detallan el proyecto de organización interna de la agencia, objetivos, personalidad jurídica y administrativa y la organización y distribución 
Este primer intento se ve truncado con la aparición de La Jornada, donde Valtierra trabaja como jefe de fotografía. Sólo seis meses subsiste la agencia, han de transcurrir dos años para que Imagenlatina resurja, pero sin mucho éxito.

El mismo día que renuncio a Unomásuno, en una marcha en el centro reúno a Marco Antonio Cruz, Jesús Carlos, Luis Humberto González y les digo: "a partir de hoy somos una agencia". Pero no había chamba, sólo mis contactos - que me llevaron a ser director de foto y cine en la Universidad de Chapingo en ese mismo tiempo-. Decidimos el nombre porque era la continuación de Unomásuno y Cámarauno porque para mí había sido fundamental, así como Cuartoscuro es la continuación del nombre de Imagenlatina. Payán ya me había dicho que hiciera el equipo para La Jornada, yo sigo trabajando en Unomásuno y el 11 de marzo renuncio y entonces fundo la agencia, en ese ínter entre la salida del Uno y el inicio de La Jornada (Valtierra, 2011). ${ }^{19}$

Al consolidarse el proyecto del diario, los miembros de la agencia se suman al equipo de fotógrafos de La Jornada, bajo la supervisión de Valtierra hasta 1986, año en que retoma la idea de Imagenlatina. Sólo cuatro meses dura este segundo intento. Conflictos entre los integrantes colisionan la cooperativa, y terminan por separarse, lo que da inicio a la agencia Cuartoscuro, formada por su familia. ${ }^{20}$

En Imagenlatina empieza a ver clientes y dinero, estamos muy bien, pero empiezan también los problemas, empezamos en abril y a los tres meses tronamos por el asunto de la dirección colectiva. La crisis estalla con el terremoto en El Salvador, al otro día me voy y cuando regreso nos reunimos y me notifican que el Consejo decidió destituirme como director por haberme ido sin autorización. Dije "esto se acabó" y me fui

del trabajo, firmados por León, Valtierra y González. El documento mecanografiado que aquí se cita fue escrito por Fabrizio León en marzo de 1984 y se encuentra resguardado en el FDPV.

En el paréntesis entre el Unomásuno y La Jornada, Valtierra dirige el departamento de Fotografía y Cine de la Universidad de Chapingo, trabajo que combina con el relanzamiento de Imagenlatina.

20 Con su salida, la agencia queda integrada por Marco Antonio Cruz, Andrés Garay que sale al poco tiempo, y Herón Alemán, que muere un mes después de la salida de Garay. Como único sobreviviente, Cruz continúa con la agencia al lado de Ángeles Torrejón. Finalmente, el proyecto se desvanece. 
con todos clientes que había conseguido (Punto, El Norte, CREA, Bellas Artes, Mañana, Vanguardia y Los Debates de Monterrey). Ya Víctor del Real y Víctor Roura me habían ofrecido un espacio en las oficinas de LaS Horas Extras, ahí empezamos la agencia Cuartoscuro (Valtierra, 2011).

\section{La consolidación. La Jornada (1984-1986 y 1995-2000)}

El primer número de este diario sale el 19 de septiembre de 1984; Valtierra estructura un programa para el departamento de fotografía con objetivos e intereses bien específicos, que marcan un parteaguas en la fotografía de prensa nacional. El texto plantea la necesidad de aprovechar los recursos técnicos y humanos con que cuenta el proyecto, "que busca que la imagen de prensa no sea tratada como lo ha sido en otros medios [...] y la responsabilidad de dar un testimonio crítico de la vida política, económica, cultural y social de este México y aquellos lugares del mundo en donde estemos". El programa es también una afirmación de preocupaciones, inquietudes y propuestas que se gestan en Unomásuno y ven en La Jornada el espacio natural para continuar. ${ }^{21}$

En dos momentos Valtierra funge en este rotativo como jefe de fotografía (1984-1986 y 1995-2000). El primero es fundamental para el diario, pues sienta las bases de un estilo fotográfico propio y se convierte en escuela de varias generaciones de fotógrafos; en el segundo periodo las cosas no resultan tan bien. En los nueve años que permanece alejado del diario la dinámica de trabajo cambia y su intento por reestructurar el departamento de foto como en sus inicios no prospera. ${ }^{22}$

21 El documento mecanografiado con fecha del 29 de febrero de 1984 se encuentra en el FDPV. El proyecto que da vida al departamento de fotografía de La Jornada en 1984 puede verse completo en Valtierra, 2008-2009. Desde el inicio del proyecto Pedro Valtierra llega a un acuerdo con Payán sobre sus negativos, éstos son de su propiedad y, en caso de salir del diario, se llevaría tanto lo realizado en Unomásuno como lo producido en La Jornada. Al dejar el diario, cumple el acuerdo y se lleva todo su material, con el que inicia el archivo de Imagenlatina.

22

En 1986 Víctor Roura y Víctor del Real, que dirigen la revista Las Horas Extras, lo invitan a coordinar el suplemento de fotografía Cuarto Oscuro, antecedente directo de la agencia de fotografía Cuartoscuro, que funda dos meses más tarde. El objetivo principal del suplemento es publicar las fotografías y reportajes que por espacio no se publican en la revista, es decir, retoman la idea de Cámara Uno (Reyes, 1994, pp. 8-13). Tras su ruptura con Imagenlatina, nace Cuartoscuro, como empresa netamente familiar. Al igual que Imagenlatina, los intereses y necesidades giran en torno a la búsqueda de un periodismo gráfico independiente y de respeto por la imagen, que trata de desarrollar 
Los dos primeros años de La Jornada son de una producción fotográfica abundante y de calidad. El género de "vida cotidiana" logra su máximo esplendor con el trabajo de Andrés Garay, Marco Antonio Cruz, Arturo Fuentes, Rogelio Cuéllar, Herón Alemán, Luis Humberto González, Fabrizio León, José Gómez de León, Rubén Pax y Frida Hartz.

Durante este periodo Valtierra cubre cuatro importantes acontecimientos. En 1985 viaja a Panamá para registrar los disturbios tras el asesinato de Hugo Spadafora por las Fuerzas de Defensa de Panamá, bajo el mando del presidente Manuel Antonio Noriega, y el terremoto que devasta la capital mexicana en septiembre, que por mucho supera al despliegue editorial del caso panameño. ${ }^{23}$

En mayo de 1985, 3500 mineros de la compañía Real del Monte en Pachuca realizan un paro de una hora en demanda de condiciones seguras e indumentaria adecuada para trabajar. La peculiar protesta consiste en despojarse de su ropa y quedarse sólo con cascos y herramientas de trabajo. Valtierra fija para la posteridad el conflicto con la secuencia "Mineros desnudos". En febrero de 1986 se da una serie de disturbios en Haití ocasionados por el golpe militar del ejército para derrocar al presidente Jean-Claude Duvalier. El domingo 10 de febrero el suplemento Perfil de La Jornada despliega doce imágenes que muestran los saqueos y enfrentamientos entre civiles y militares.

un trabajo informativo visual que refleje los acontecimientos más importantes del país en todos los ámbitos. Por la agencia han desfilado más de 120 fotógrafos a lo largo de 30 años. El Banco de imágenes, dividido en dos archivos (negativo de $35 \mathrm{~mm}$ y digital), tiene un acervo formado por cerca de 800 mil imágenes que registran la historia del país de 1979 a la fecha y brinda su servicio a más de cien medios. En 1993 surge la revista bimestral que comparte el nombre de la agencia y que busca apoyar a los fotógrafos jóvenes de todo el país. Cuartoscuro. Revista de fotógrafos, es un espacio independiente que se ha convertido en referente para la divulgación de la imagen fotográfica donde caben ensayos y portafolios fotográficos, hasta colecciones de acervos del resto del país; la revista representa un escaparate para todos los géneros fotográficos y en sus páginas se han publicado portafolios tanto de fotógrafos incipientes como reconocidos. Es un espacio de diálogo, debate y reflexión abierto entre periodistas, escritores, fotógrafos, historiadores y lectores interesados en la imagen fotográfica. El documento titulado Proyecto para la formación de la Agencia de fotografía Cuartoscuro puede consultarse en el FDPV. A partir de 1983 Valtierra imparte talleres, cursos y conferencias de fotoperiodismo mexicano a medios de comunicación y universidades, participa en congresos y coloquios, es invitado como jurado de concursos fotográficos, continúa exponiendo de manera individual y colectiva en el país y el extranjero y se involucra aún más en agrupaciones de fotógrafos. 
El primer periodo en La Jornada termina por conflictos sindicales y pugnas con miembros de la mesa directiva; por otro lado, Valtierra se enfrenta con Héctor Aguilar Camín por la opuesta concepción que ambos tienen del periodismo y la fotografía de prensa. ${ }^{24}$ La tensión llega al máximo y Valtierra decide renunciar; como muestra de solidaridad lo siguen Marco Antonio Cruz, Andrés Garay, Rubén Pax y Arturo Fuentes. También renuncian Miguel Ángel Granados Chapa y Humberto Musacchio. Esta salida da paso al relevo generacional. Quienes permanecen -Fabrizio León, Luis Humberto González, Frida Hartz y Rogelio Cuéllar, que queda como jefe del departamento- hacen un nuevo equipo con los que llegan -Francisco Mata, Arturo Guerra, Elsa Medina, Ireri de la Peña y Raúl Ortega-.$^{25}$

La producción de Valtierra durante su periodo en La Jornada es prolífica. Explota al máximo su capacidad de ver y componer imágenes extraídas de la vida cotidiana, siguiendo los parámetros que caracterizan al nuevo fotoperiodismo mexicano de los que hemos venido hablando. Esta habilidad de fotografiar en el momento y lugar oportuno de forma irónica, desenfadada y con alto contenido político-social se muestra en la imagen de Luis Donaldo Colosio y Carlos Salinas de Gortari en los viveros de Coyoacán. En 1985 logra su cenit durante la cobertura del terremoto de la ciudad de México. En este contexto Valtierra logra imágenes que al poco tiempo se convirtieron en iconos de la tragedia capitalina, como el policía que camina frente a las ruinas del hotel Regis en el corazón de la ciudad, o aquéllas captadas en el estadio de beisbol, convertido en esos días una inmensa morgue por donde desfilaban familias enteras buscando a sus desaparecidos.

24 A pesar del lugar que la fotografía de prensa había ganado, aún existían posturas que la consideraban relleno o ilustración de la nota; uno de ellos era Aguilar Camín, que colocaba las imágenes de acuerdo con el espacio que quedaba libre en la página. Valtierra, con la experiencia adquirida como fotorreportero y jefe de fotografía, consideraba que la imagen debía tener un lugar igual de importante que los textos. Estas posturas opuestas hicieron inevitables los enfrentamientos entre ambos. Granados Chapa, la revista Mira. El periodista es el director general y Valtierra director y fotógrafo; la agencia Cuartoscuro es la encargada de proveer a la revista de imágenes. Valtierra renuncia a la dirección en mayo de 1991, pero continúa colaborando hasta 1994, año en que cierra la publicación. De acuerdo con el editorial (1990, 14 de febrero p. 1), la revista tiene como principal objetivo abrir espacios a la fotografía de prensa en México, con la convicción de que "un amplio y calificado sector del público, formado en la cultura visual característica de nuestro tiempo, apreciará que revaloremos el lenguaje de la imagen como elemento principal y no accesorio del mensaje que proponemos" (documento mecanografiado, FDPV). 


\section{Imagen 8}

Terremoto en la ciudad de México

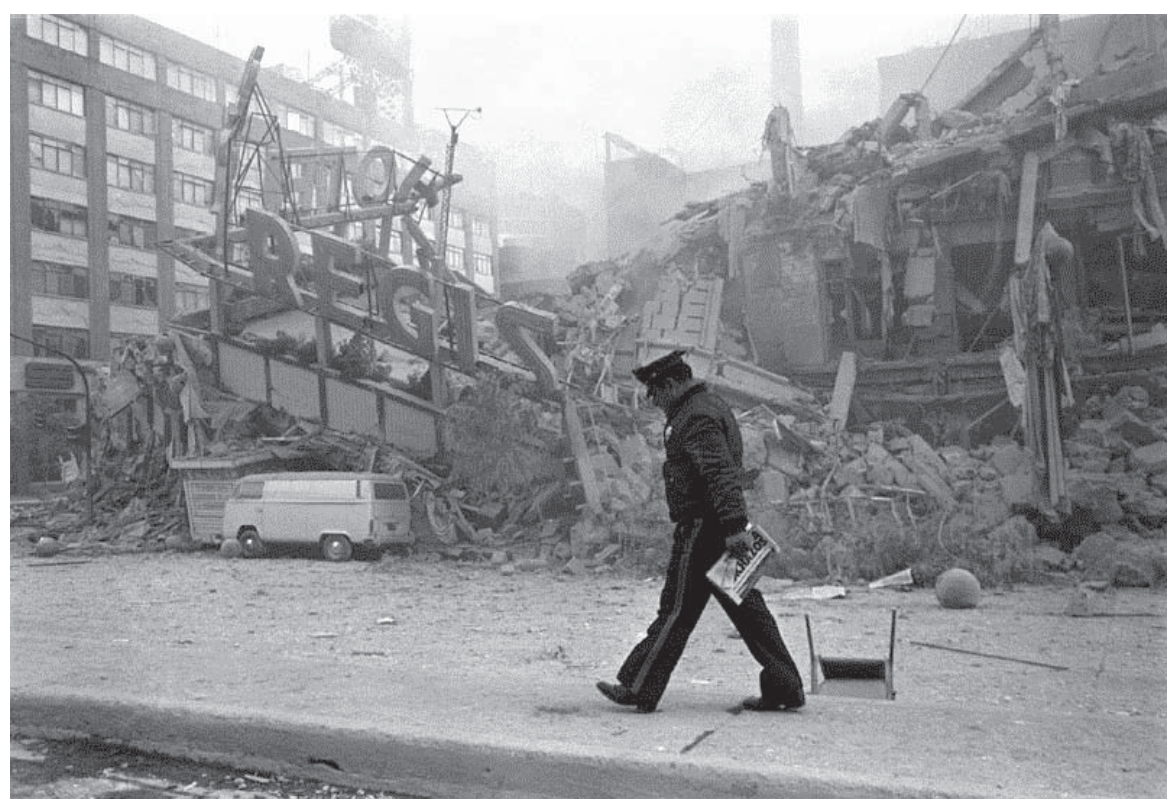

México, 1985, Pedro Valtierra, Banco de Imágenes, Cuartoscuro.

\section{Imagen 9}

Disturbios tras el derrocamiento de Jean-Claude Duvalier

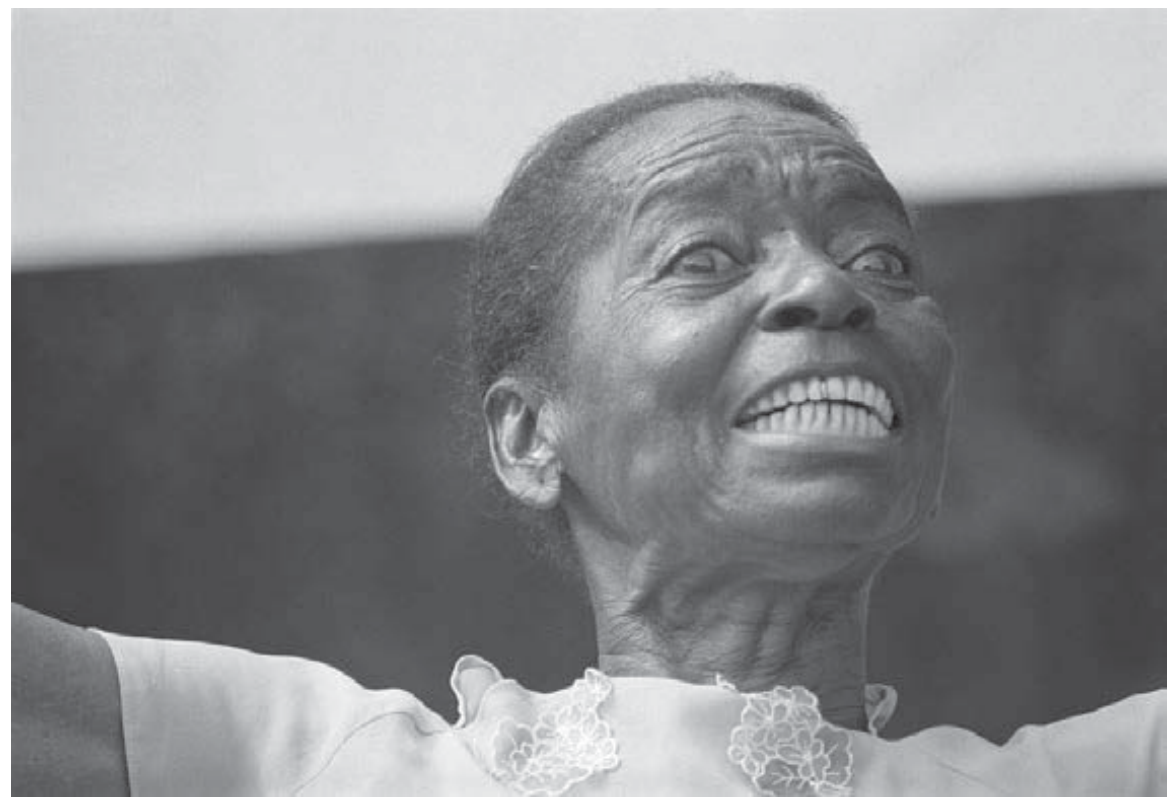

Haití, 1986, Pedro Valtierra, AFPV. 


\section{Imagen 10}

Carlos Salinas de Gortari y Luis Donaldo Colosio en los Viveros de Coyoacán

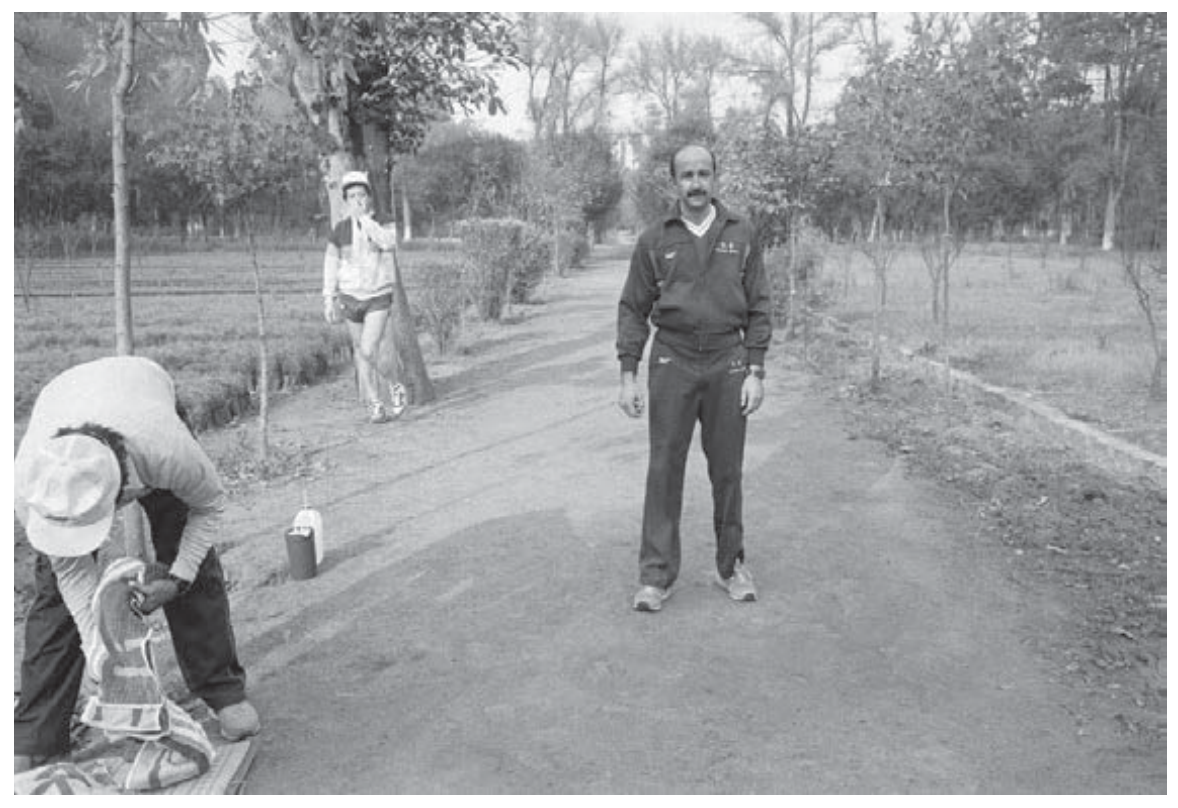

México, 1987, Pedro Valtierra, Banco de Imágenes, Cuartoscuro.

\section{Imagen 11}

"Mujeres de Altamirano"

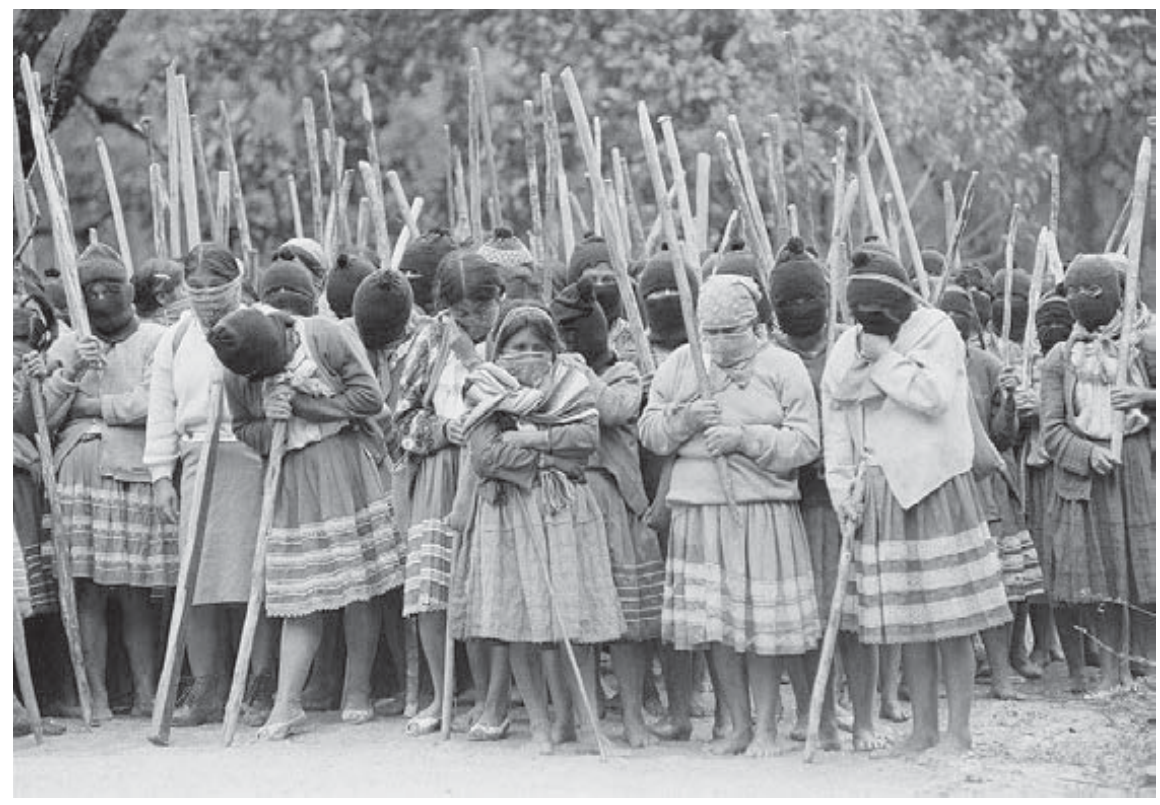

Chiapas, México, 1998, Pedro Valtierra, AFPV. 
En diciembre de 1995 Valtierra regresa a La Jornada como coordinador y continúa trabajando en su agencia. El rotativo está consolidado como uno de los diarios más importantes del país. Las cosas han cambiado y el departamento de fotografía no escapa a ello, por lo que Valtierra no logra hacer mucho en el ámbito colectivo del departamento, no así en el espacio personal.

El levantamiento zapatista de 1994 posiciona al diario como el principal vocero de los rebeldes. Valtierra, al igual que muchos fotorreporteros, viaja a Chiapas y registra múltiples ángulos del ejército insurgente y del subcomandante Marcos. Su trabajo en Chiapas es de lo más destacado en este periodo. En diciembre de 1997 se registra una matanza en el poblado de Acteal y la prensa internacional se traslada al sureste mexicano. El sábado 3 de enero de 1998, Juan Balboa y Pedro Valtierra se internan en el municipio de X'oyep, donde captura la imagen que en octubre de ese mismo año lo lleva a Madrid a recibir el premio Rey de España por la mejor imagen noticiosa de 1998, otorgado por la agencia EFE.

\section{Imagen 12}
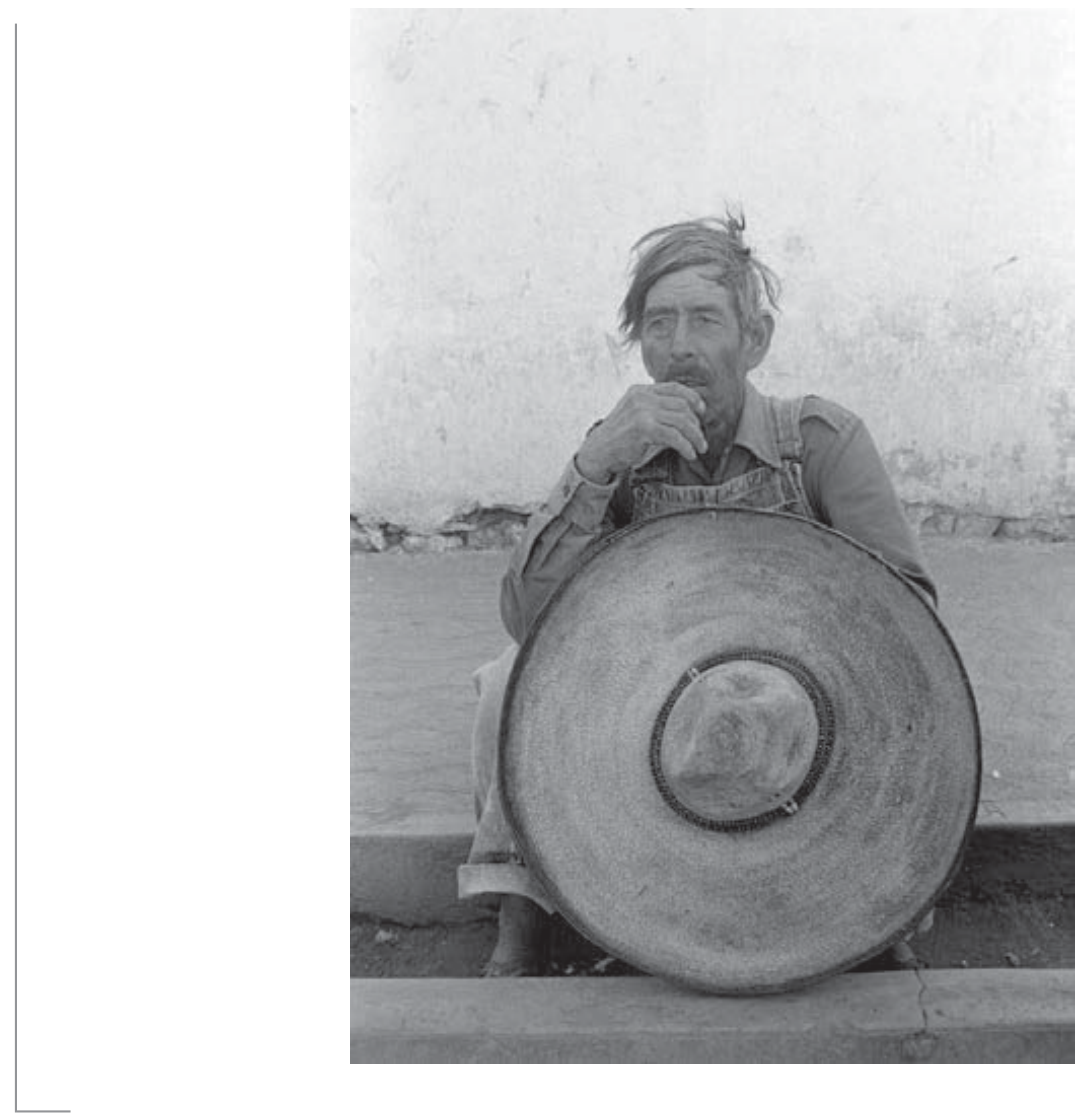

Zacatecas, 1986, Pedro Valtierra, AFPV. 


\section{Imagen 13}

La Honda, Municipio de Miguel Auza

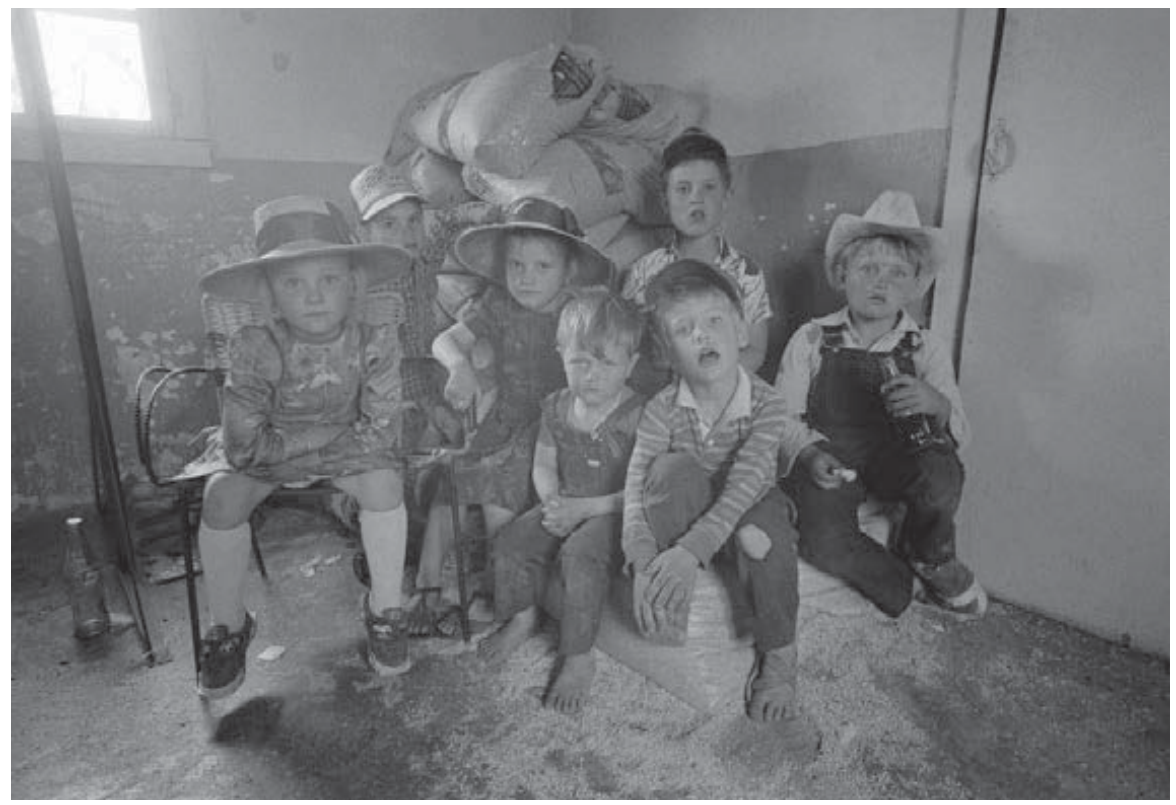

Zacatecas, 1986, Pedro Valtierra, AFPV.

\section{Imagen 14}

Rito popular del Niño Fidencio, Comunidad de Espinazo

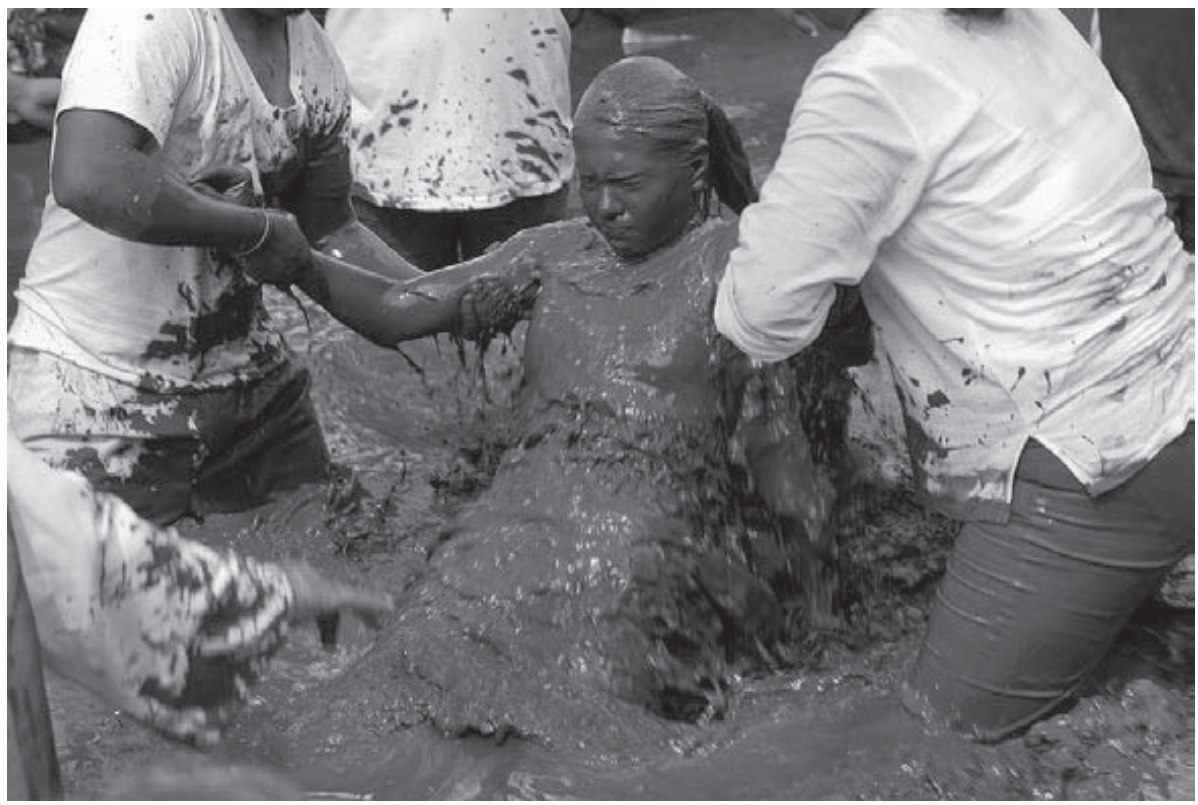

Nuevo León, 2006, Pedro Valtierra, AFPV. 


\section{Imagen 15}

Rito popular del Niño Fidencio, Comunidad de Espinazo

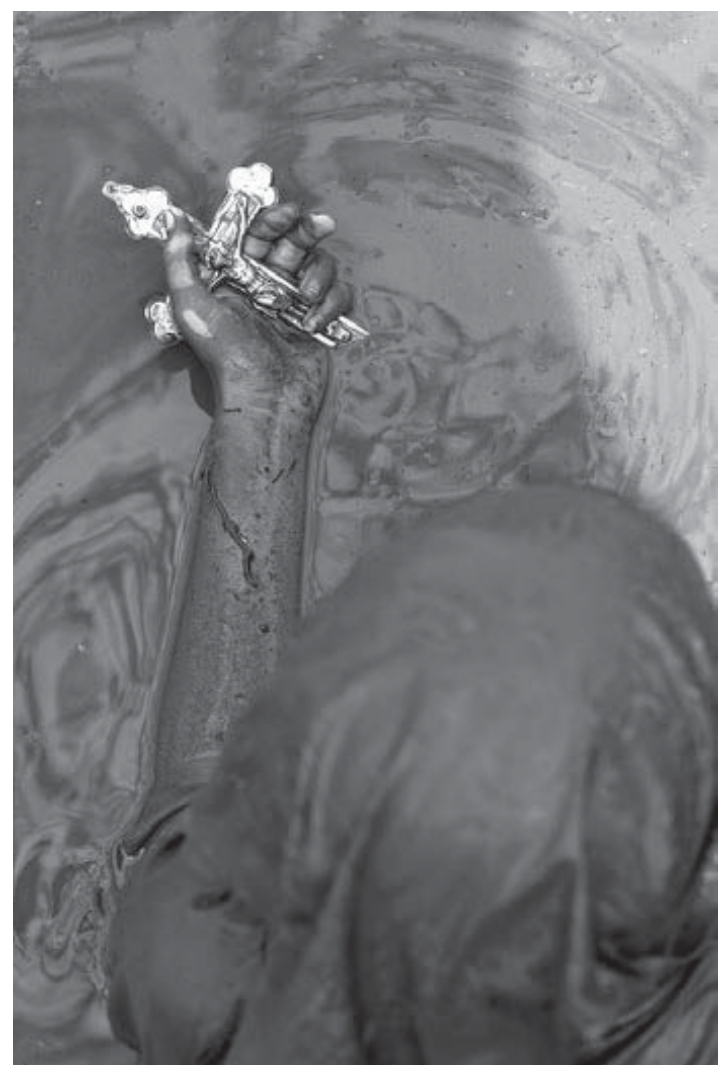

Nuevo León, 2006, Pedro Valtierra, AFPV.

Como responsable del área, la producción de Valtierra disminuye; ahora su labor es formar nuevas generaciones. Sin embargo, eventualmente desarrolla fotorreportajes de largo alcance, como el de los indocumentados en la frontera norte del país, continúa con los proyectos de Zacatecas y el Niño Fidencio que había comenzado en las décadas de los setenta y ochenta, y viaja a Cuba para la primera visita de Juan Pablo II a la isla.

En 2000 renuncia definitivamente a La Jornada por desavenencias directas con Carmen Lira que tienen que ver con la forma de concebir la imagen de prensa y la forma de dirigir el departamento de fotografía. ${ }^{26} \mathrm{~A}$ partir de entonces se dedica a la agencia y la revista y a desarrollar otro proyecto que pone en marcha en 2005, la Fototeca del estado de Zacate-

26 Valtierra ha evitado ahondar en el conflicto con Lira argumentando un conflicto de intereses. Por su parte, Carmen Lira no ha accedido a hablar de este tema. 
cas, con el apoyo del gobierno estatal, y continúa con sus dos fotoensayos de Zacatecas y el Niño Fidencio. ${ }^{27}$

\section{Para finalizar}

Pedro Valtierra pertenece a una gran generación de fotorreporteros mexicanos y su trabajo está supeditado a los diversos medios de comunicación donde ha laborado y los contextos en los que se ha desarrollado. Por tanto, no es casual sino causal que sus imágenes tengan un enfoque social muy claro y determinado.

Como se ha dicho, no se trata de un caso aislado ni del paradigma del fotoperiodista mexicano; por el contrario, Valtierra es producto de circunstancias particulares, momentos históricos específicos, avances técnicos y estéticos de la fotografía mexicana, convivencia con colegas y aprendizaje de maestros, editores y directores. Su trabajo es el resultado de la suma de estas condiciones y así es como debe leerse su trayectoria, sin negar la influencia que ha tenido en generaciones posteriores al convertirse en maestro, ni el lugar destacado que logró durante los años que estuvo activo y que aún conserva entre sus colegas y miembros de su generación, por su audacia que le permitió registrar momentos históricos del continente americano y que lo hicieron acreedor a reconocimientos a nivel internacional, por su agudeza en el momento de mirar y retratar una parte de la realidad desde su propia visión del mundo, que le permitió desarrollar un estilo estético propio, como una mirada individual enfocada en los problemas sociales de México y América Latina.

El lugar que Pedro Valtierra ocupa en la historia del fotoperiodismo mexicano lo adquirió gracias a los múltiples e importantes acontecimientos históricos que le tocó cubrir para los diversos medios escritos del país; sin embargo, la cobertura de la revolución sandinista significa el parteaguas en su trayectoria como fotógrafo de prensa y corresponsal de guerra. A partir de ese momento no hace más que consolidarse como un joven enviado que registra con un ojo guiado por un interés específico las décadas más convulsas del continente.

La trayectoria de Valtierra alcanza los 42 años, pero su etapa más fructífera e importante como fotógrafo comprende los años de 1975 a 2000, razón por la cual este texto estudia este periodo. Como empresario y

$27 \quad$ El proyecto de la Fototeca de Zacatecas que lleva su nombre nace en 2005, y un año más tarde se pone en marcha con el objetivo primordial de recuperar, rescatar y difundir el patrimonio visual del estado, así como la enseñanza de la fotografía y la presentación e itinerancia de más de cien exposiciones fotográficas. 
maestro, sigue activo a través de su agencia y su revista de fotografía. Sin duda es un referente obligado en la historia del fotoperiodismo mexicano $\mathrm{y}$, aun sin acercarnos a sus fotos desde los estudios visuales, es decir, leerlas y analizarlas, recuperar su testimonio permite reconstruir un momento de efervescencia estética, social, cultural y política de la fotografía mexicana.

Explorar la trayectoria de Valtierra, como fotorreportero y "animal político", no sólo nos permiten ubicar su trabajo de forma particular, sino que nos da sobre todo la oportunidad de enmarcarlo en momentos coyunturales de la historia de la fotografía de prensa mexicana y desde ahí leerlo de una forma mucho más amplia, es decir, una lectura diacrónica y sincrónica. Por otro lado, su carrera, ligada a la indisoluble relación prensa-política del país, hizo posible acercarnos a él dejando en segundo plano sus fotografías, pues su trayectoria refleja un momento particular de la prensa en México y resulta determinante abordarlo desde otros ángulos más allá de sus negativos.

Por lo tanto, este acercamiento forma parte de la necesaria recuperación de su trabajo y el de otros fotorreporteros nacionales, para armar lentamente y con piezas sólidas el gran rompecabezas que representa el periodismo gráfico y que sin duda abonará en la construcción de la historia de la fotografía mexicana. Detenerse a estudiar el trabajo de Pedro Valtierra es acercarse a escenarios generales del país y particulares de la fotografía de prensa nacional.

\section{Siglas y referencias}

AFPV Archivo Fotográfico Pedro Valtierra

Banco de Imágenes Cuartoscuro

FDPV Fondo Documental Pedro Valtierra

Dibujos y escritos personales de Pedro Valtierra, 1970-1972,

México.

Colectiva de Fotógrafos Unidos. Estatutos, octubre de 1981,

México.

Diario de campo en Guatemala, 1982, México.

Carta sin título (conflicto Unomásuno), 5 de diciembre de 1983, México.

Imagenlatina. Estatutos, marzo de 1984, México.

Proyecto para el laboratorio de fotografía de La Jornada, 29 de febrero de 1984, México.

Proyecto para la formación de la agencia de fotografía Cuartoscuro, s/f, México. 


\section{Hemerografía}

El Sol de México,13 de marzo de 1977.

El Sol de Mediodía, 12 de octubre de 1978, p. 1.

El Financiero, Sección cultura, 9 de junio de 1989, p. 80.

Por esto!, número 48, 27 de mayo de 1982.

Por esto!, número 49, 3 de junio de 1982.

Por esto!, número 50, 10 de junio de 1982.

Por esto!, número 51, 17 de junio de 1982.

Unomásuno, 26 de octubre de 1978.

La Voz Estudiantil, 1974.

Revista Mira, 14 de febrero de 1990.

Unidad, año 1, núm. 1, 26 de junio de 1979.

\section{Bibliografía.}

Aceves, J. (2000)

Historia oral: ensayos y aportes de investigación, México: Centro de Investigaciones y Estudios Superiores en Antropología Social.

Burke, P. (2001)

Visto y no visto. El uso de la imagen como documento histórico. Madrid: Crítica.

Castillo, A. del, y R. Moya (2011) Una mirada documental al México de mediados del siglo Xx, México: La Jornada, Ediciones El Milagro, Universidad Nacional Autónoma de México-Instituto de Investigaciones Estéticas, Fondo Nacional para la Cultura y las Artes.

Castillo, A. del (2013)

Las mujeres de X'oyep. La historia detrás de la fotografía, México: Consejo Nacional para la Cultura y las Artes de México.

Castillo, A. del y M. Morales (2012)

Pedro Valtierra. Mirada y testimonio, México: Universidad Nacional Autónoma de México, Fondo de Cultura Económica, Cuartoscuro.

Cherem, S. (2010)

Por la izquierda. Medio siglo de historias en el periodismo mexicano contadas por Granados Chapa, México: Khalida editores.

Fontcuberta, J. (1994)

Fotografía. Conceptos y procedimientos: una propuesta metodológica. México: Gustavo Gilli.

Gallegos, L. J. (2011)

Autorretratos del fotoperiodismo mexicano. 23 testimonios, México, Fondo de Cultura Económica.

Kossoy, B. (2001)

Fotografia e Historia, Buenos Aires: Lamarca. 
Monroy, R. (2001)

"Siluetas sobre la lectura fotográfica", en M. Camarena y L. Villafuerte, Los andamios del historiador. Construcción y tratamiento de fuentes, México, Archivo General de la Nación, Instituto Nacional de Antropología e Historia, pp. 317-336.

Monroy, R. (2005)

"A corazón abierto: una aproximación metodológica a la investigación fotohistórica", en L. Roca y F. Aguayo (coord.), Imágenes e investigación social, México: Instituto Mora.

Morales, M. (2014)

Nicaragua 1979. La mirada de Pedro Valtierra. La cobertura fotoperiodística de la revolución sandinista en el diario Unomásuno, tesis de doctorado inédita, Escuela Nacional de Antropología e Historia.

Morales, M. (2016)

"Pedro Valtierra, corresponsal en Nicaragua. Reconstrucción de la trayectoria de un "Balazo" fotográfico", en Estudios históricos sobre cultura visual. Nuevas perspectivas de investigación, México: Instituto Mora, El Colegio de Michoacán.

Mraz, J. (1996)

La mirada inquieta: nuevo fotoperiodismo mexicano: 1976-1996, México: Consejo Nacional para la Cultura y las Artes de México.

Reyes, A. (1994)

"De Zacatecas para el mundo", en Revista Hormigas, Zacatecas, pp. 8-13.

Rodríguez, S. (2012)

La mirada crítica del fotorreportero Pedro Valtierra, (1977-1986), tesis de maestría inédita, México: Universidad Nacional Autónoma de México.

Valtierra, P, (2008-2009)

"El proyecto que fue", Cuartoscuro, México, año Xv, números 93-95.

Wolfe, T. (1977)

El nuevo periodismo, Barcelona: Anagrama.

\section{Entrevista}

Valtierra, Pedro Entrevista realizada el 16 de agosto y el 9 de diciembre de 2011 en la ciudad de México. Entrevistadora: Mónica Morales.

Recibido: 02/02/2016. Aceptado: 04/06/2016 